\title{
Native Species Regeneration Following Ungulate Exclusion and Nonnative Grass Removal in a Remnant Hawaiian Dry Forest ${ }^{1}$
}

\author{
Farrod M. Thaxton, ${ }^{2,3,8}$ T. Colleen Cole, ${ }^{2,4}$ Susan Cordell, ${ }^{2}$ Robert 7. Cabin, ${ }^{5}$ \\ Darren R. Sandquist, ${ }^{6}$ and Creighton M. Litton ${ }^{7}$
}

\begin{abstract}
Hawaiian lowland dry forests have been reduced by $>90 \%$ since first human contact. Restoration has focused on protection from fire and ungulates, and removal of invasive grasses as ways to stimulate native forest regeneration. Despite these efforts, natural regeneration of native plants has been infrequent. To assess effects of previous restoration treatments on natural regeneration, we monitored seed rain and dynamics of seedlings and juveniles for a period of $3 \mathrm{yr}$ (2004-2007) within three restoration units within a remnant forest on the island of Hawai'i. All units had been protected from fire for many decades but differed in time since ungulate exclusion and grass removal. The units were as follows: (1) long-term restoration (fenced 1956, grass removal initiated 1995), (2) shortterm restoration (fenced and grass removal initiated 1997), and (3) unmanaged (fenced 1997, no grass removal). Overall juvenile plant abundance was highest in the short-term unit, but native abundance was highest in the long-term unit. Native woody seedlings established in all units, but recruitment into larger size classes was restricted to units with grass removal, primarily the long-term unit. Native seed rain explained much of the variation in native seedling abundance between units with grass removal. Nonnative grass seed rain was extensive but was reduced by an order of magnitude with grass removal. This study suggests that natural regeneration may enhance restoration actions in sites with native canopy, but this is likely only when restoration activities have been maintained for several years to coincide with favorable rainfall conditions that are highly unpredictable over time.
\end{abstract}

Tropical DRY FORESTs are one of the most endangered ecosystems in the world. Almost all of the remaining tropical dry forests $(\sim 97 \%)$ are at risk from multiple threats such as fire, fragmentation, and human land use (Miles et al. 2006). In many regions, $<0.1 \%$ of the original dry forests have been protected (Janzen 1988, Bullock et al. 1995).

\footnotetext{
${ }^{1}$ Funding for this study was provided by the U.S. Forest Service and U.S. Department of Agriculture National Research Initiative Grant 2002-00631 to R.J.C., S.C., and D.R.S. Manuscript accepted 24 December 2009.

2 U.S. Department of Agriculture Forest Service, Institute of Pacific Islands Forestry, Hilo, Hawai'i 96720.
}

Pacific Science (2010), vol. 64, no. 4:533-544

doi: $10.2984 / 64.4 .533$

(C) 2010 by University of Hawai'i Press

All rights reserved
In Hawai'i, tropical dry forests have been reduced to less than $10 \%$ of their original area (Bruegmann 1996). This decline represents a substantial loss of biodiversity because these forests were once described as the most diverse in the Hawaiian archipelago (Rock 1913). Currently, remnant dry forests have the highest proportion of endangered taxa

\footnotetext{
${ }^{3}$ Department of Biology, University of Puerto Rico, Mayagüez, Puerto Rico 00681.

4 Three Mountain Alliance, Hawai'i Volcanoes National Park, Hawai'i 96718.

${ }^{5}$ Divison of Science and Math, Brevard College, Brevard, North Carolina 28712.

${ }^{6}$ Department of Biological Science, California State University, Fullerton, California 92831.

7 Department of Natural Resources and Environmental Management, University of Hawai'i at Mānoa, Honolulu, Hawai'i 96822.

${ }^{8}$ Corresponding author (e-mail: jthaxton20@gmail .com).
} 
among Hawaiian plant communities (Sakai et al. 2002), and native species continue to decline within these remnants due to lack of natural regeneration (Cabin et al. 2000, Litton et al. 2006). Conservation of remnant dry forests is thus critical, and their successful restoration is likely to depend on overcoming barriers to natural regeneration.

Restoration and management activities in Hawaiian tropical dry forests have had limited success in stimulating natural seedling recruitment of native woody species. There are no "pristine" forests that may serve as reference sites to guide restoration. All surviving remnants have been degraded by nonnative ungulates and rodents, invasive plants, or human-caused fires (Cuddihy and Stone 1990, Smith and Tunison 1992). Some of the best remaining remnants are found in the North Kona district of the island of Hawai'i, but previous studies have indicated that even there seedling regeneration does not occur without the exclusion of grazing ungulates (Cabin et al. 2000). Furthermore, even with ungulate exclusion and seed augmentation, regeneration continues to be strongly limited by nonnative grasses (Cabin et al. 2000, $2002 b$ ). Few native seedlings establish within forest stands dominated by nonnative grass, and even fewer recruit into larger size classes (Litton et al. 2006). Even when grasses are removed and native seed sources are present, natural seedling regeneration, particularly of native tree species, is rare (Cabin et al. 2002a).

Regeneration in dry forests may be dependent on periods of high rainfall. Studies in highly seasonal neotropical dry forests indicate that seedling establishment and survival are positively affected by soil moisture (Blain and Kellman 1991, Gerhardt 1996, McLaren and McDonald 2003). Similarly in Hawai'i, Cabin et al. (2002a) found that supplemental watering was critical to success of restoration plantings, and that only after an unusually wet period was any natural regeneration observed (Cabin et al. 2000). Furthermore, many Hawaiian dry-forest species initiate flowering and fruit production in response to rainfall (S.C., unpubl. data). These patterns suggest that stimulation of natural regeneration may be highly dependent on the timing of restoration activities in relation to rainfall.
We assessed the potential for ungulate exclusion and nonnative grass removal to promote natural regeneration within Hawaiian lowland dry forest remnants. More specifically, we investigated whether seed rain and abundance of seedlings and juveniles differed between three sites with similar native canopy but different histories of ungulate exclusion and grass removal. We timed our measurements of seed rain, seedling abundance, and recruitment to coincide with a $2-y r$ period (2004-2005) of unusually high rainfall (218\% and $132 \%$ of normal, respectively). We expected that differences in regeneration patterns among sites might be most evident following this period of high rainfall.

\section{MATERIALS AND METHODS}

We conducted our study at the Ka'ūpūlehu Preserve in North Kona on the island of Hawai'i (19 $\left.46^{\prime} 05^{\prime \prime} \mathrm{N}, 155^{\circ} 56^{\prime} 19^{\prime \prime} \mathrm{W}\right)$. The preserve is located at $600 \mathrm{~m}$ elevation on 1,500 - to 3,000-yr-old ' $a$ ' $\bar{a}$ lava (Moore et al. 1987) and encompasses 231 ha of remnant lowland dry forest dominated by the native trees Diospyros sandwicensis (lama), Metrosideros polymorpha ('ōhi'a), and Psydrax odorata (alabe $e^{6}$ ). Pennisetum setaceum (African fountain grass) has extensively invaded all parts of the preserve, and grass removal has been a focus of restoration activities (Cabin et al. 2000). The entire preserve has been actively protected from fire for the past $10 \mathrm{yr}$, and there is no evidence that any part of the preserve has burned within the past several decades.

Total annual rainfall is low, but annual variation is high. From 1999 to 2007, annual rainfall at $\mathrm{Ka}$ ' ūpūlehu averaged $537 \mathrm{~mm}$ with a maximum of $1,249 \mathrm{~mm}$ in 2004 and a minimum of $225 \mathrm{~mm}$ in 1999 (Figure 1). A longer-term record (40 yr, 1967-2007) for a nearby site (Hu'ehu'e Ranch, $19^{\circ} 45^{\prime} 24^{\prime \prime} \mathrm{N}$, $155^{\circ} 58^{\prime} 28^{\prime \prime} \mathrm{W}$; http://www.wrcc.dri.edu) showed an average of $587 \mathrm{~mm}$ (range: 203$1,363 \mathrm{~mm}$ [Figure 1]). Rainfall is not distinctly seasonal, and substantial rainfall can occur in any month, but summer months tend to be drier than winter (Cordell and Sandquist 2008).

The Ka'ūpūlehu Preserve contains three contiguous restoration units that differ in 


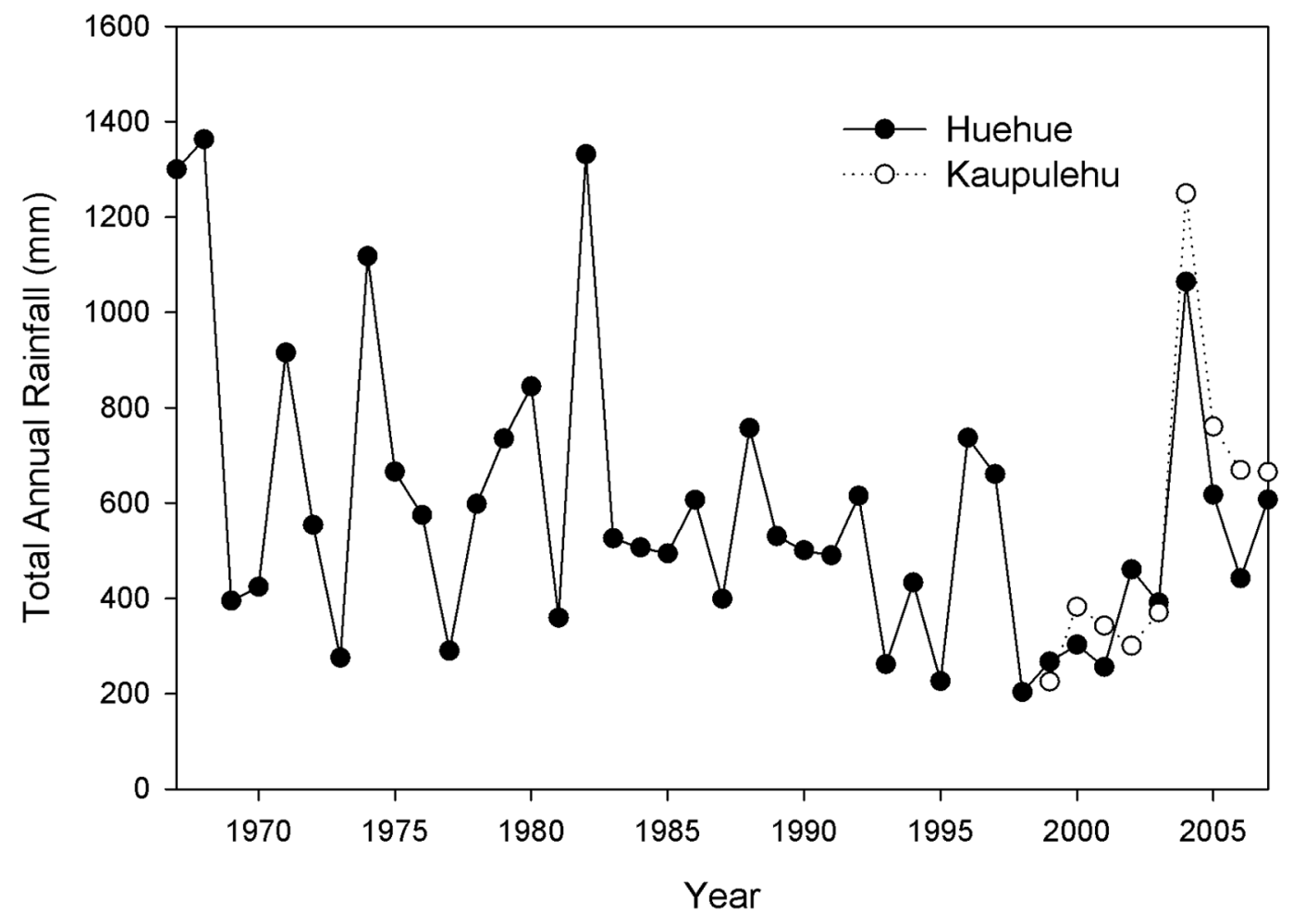

Figure 1. Total annual rainfall for our field site (Ka'ūpūlehu, 1999-2007) and a nearby site (Hu'ehu'e Ranch, 19672007) at similar elevation.

time since initiation of ungulate exclusion and grass removal. The "long-term restoration" unit contains 2.3 ha that have been protected from ungulate browsing since 1956. Grass removal was initiated in 1995, and the exclosure has been relatively free of nonnative species since that time (Cabin et al. 2000, Cabin et al. 2002a). Both the "shortterm restoration" unit and "unmanaged" unit (28.3 ha total) were fenced in 1997. Within the short-term unit ( 3 ha), grass removal was initiated in 1997, but in the unmanaged unit ( $\sim 25$ ha) no grass removal has occurred. All three units are adjacent to each other, with a paved highway separating the long-term unit from the others, and a small dirt road separating the short-term from the unmanaged unit.

To compare diversity and abundance of juveniles among restoration units (hereafter "sites"), we installed three $50 \mathrm{~m}$ transects within each site in May 2004. All transects were located under forest canopy dominated by $D$. sandwicensis. Importance values for D. sandwicensis calculated for transects within sites using a point-centered quarter method averaged 262 and did not differ significantly among sites (one-way analysis of variance [ANOVA], $F=1.81 ; \mathrm{df}=2,6 ; P=.24)$. Although canopy condition was similar among the sites, the long-term restoration site did contain a more developed native shrub understory (Cabin et al. 2000) that was largely absent from the short-term restoration and unmanaged sites.

We permanently established $1-\mathrm{m}^{2}$ plots at $5 \mathrm{~m}$ intervals along each transect for a total of 30 plots per site and 90 total plots in the study. From May 2004 to June 2007, we monitored all juvenile plants within each plot. Juveniles were defined as all plants with true leaves and $<1 \mathrm{~m}$ in height. By sampling plants up to $1 \mathrm{~m}$ height, we were able to monitor both seedlings and young juveniles. Based 
on our observations, only at heights $>1 \mathrm{~m}$ do juveniles begin to emerge above the grass groundcover. We conducted censuses every 4-7 months for a total of seven censuses during the study period. At each census, we identified all individuals to species and recorded the number and height of each. During the initial census in May 2004, we marked any plants within each plot that were larger than $1 \mathrm{~m}$ but smaller than canopy trees. These plants were excluded from further censuses. At subsequent censuses, we continued to mark and count juveniles that had emerged above $1 \mathrm{~m}$ height since the previous census. Also during the censuses, we tagged newly emerging individuals of all native woody species that were found within the plots.

We used seed traps to quantify seed rain across sites. One trap was mounted on a rebar stake at a corner of each seedling plot. Seed trap design followed Cottrell (2004). Each trap consisted of an $18 \mathrm{~cm}$ diameter plastic funnel with a small wire-mesh pouch attached to the bottom. Total seed trap area was 0.025 $\mathrm{m}^{2}$. The weave of the mesh was fine enough to collect all seeds yet still allow water to pass through. The funnel was attached by wire to a short length of $5.08 \mathrm{~cm}$ diameter polyvinyl chloride (PVC) pipe to protect the mesh pouch from seed predators and raise the trap to a height $\sim 1 \mathrm{~m}$ above ground level. Traps were placed in the field in November 2004 and collection began in December 2004. Seed traps were collected every month for the first 5 months and thereafter every 4 months until April 2007. All seeds were counted and identified to species.

Our study compared regeneration among three unreplicated sites that differed in restoration history located within a single preserve. This experimental design resulted in large part from the extreme rarity of longterm restoration sites in Hawaiian tropical dry forest. In particular, our long-term restoration site is unique among Hawaiian lowland dry forests; no other site has been fenced for a comparable length of time (>50 yr). Given this lack of replication, we constructed statistical tests using plots within sites as experimental units. This resulted in pseudoreplication at the site level. To account for this, we limited our inference to differences among sites rather than more general inferences about the effects of ungulate exclusion and grass removal. Furthermore, we minimized site level variation unrelated to management history by locating plots on similar substrate ages and in areas with similar canopy composition and structure.

We used PROC MIXED in SAS (SAS Institute 2002-2003) to compare seed and juvenile plant dynamics among sites. We used repeated-measures ANOVA to assess changes in overall and native plant abundance, as well as seed rain of both native species and Pennisetum setaceum, within restoration units over time. Site and time were treated as fixed effects with plots nested within transects as experimental units. To account for unequal spacing between census periods, we used a spatial power covariance structure in all models (Littell et al. 1996). We transformed the data for overall juvenile plant abundance (natural $\log +1)$, juvenile plant native proportion (arcsin square root), and seed rain (natural $\log +1)$ to meet model assumptions. A oneway ANOVA with site as the fixed factor was used to compare woody native species recruitment into larger size classes over the entire study period.

We used two approaches to explore differences among treatment means for all analyses. First we used two single degree of freedom linear contrasts to test a priori hypotheses of differences between restoration units. The first contrast tested the hypothesis that the "unmanaged" unit differed from the grass removal units as a whole ("short-term" plus "long-term"). The second contrast then tested the hypothesis that the two grass removal units ("short-term" versus "longterm") differed from each other. To explore causes of significant interactions, we used the SLICE option on the SAS LSMEANS statement to assess estimates of simple main effects.

\section{RESULTS}

Over the study period, we counted a total of 5,123 juvenile plants of 36 species ( 21 nonnative, 15 native). In three of the four census years $(2004,2005,2007)$, total species richness was highest in the long-term restoration site, intermediate in the short-term restora- 
TABLE 1

Average Juvenile Abundance (Individuals $/ \mathrm{m}^{2}$ ) for 2004-2007 within Long-Term (LT), Short-Term (ST), and Unmanaged (U) Units at the Ka'ūpūlehu Preserve on the Island of Hawai'i (Species Are Ordered from Most to Least Abundant by Growth Form)

\begin{tabular}{|c|c|c|c|c|c|c|c|c|c|c|c|c|}
\hline \multirow[b]{2}{*}{ Scientific Name } & \multicolumn{3}{|c|}{2004} & \multicolumn{3}{|c|}{2005} & \multicolumn{3}{|c|}{2006} & \multicolumn{3}{|c|}{2007} \\
\hline & $\mathrm{U}$ & ST & LT & $\mathrm{U}$ & $\mathrm{ST}$ & LT & $\mathrm{U}$ & ST & LT & $\mathrm{U}$ & ST & $\mathrm{LT}$ \\
\hline \multicolumn{13}{|l|}{ Canopy trees } \\
\hline Diospyros sandwicensis & & & 0.1 & 0.13 & & 1.30 & 0.10 & & 0.40 & 0.07 & & 0.27 \\
\hline Psydrax odorata & 0.6 & & & 0.60 & & & 0.78 & & 0.02 & 0.27 & & \\
\hline \multicolumn{13}{|l|}{ Shrubs and small trees } \\
\hline Nototrichium sandwicense & & & 0.27 & & 0.03 & 0.43 & & & 2.98 & & & 0.37 \\
\hline Sida fallax & & 0.37 & 0.33 & & & 0.63 & & 1.40 & 0.12 & & 0.47 & 0.07 \\
\hline Lantana camara* & 0.03 & 0.13 & 0.1 & 0.03 & 0.03 & 0.20 & 0.03 & 1.18 & 1.02 & 0.07 & 0.20 & 0.10 \\
\hline Sophora chrysopylla & & & 0.23 & & 0.03 & 0.13 & & & 0.18 & & & 0.10 \\
\hline Chenopodium oahuense & & & 0.1 & & & 0.17 & & & 0.08 & & & 0.10 \\
\hline Lipochaeta subcordata & & & 0.2 & & 0.03 & 0.13 & & & 0.03 & & & \\
\hline Schinus terebinthifolius* & & & & & 0.13 & 0.03 & & & 0.05 & & & \\
\hline Leucaena leucocephala* & & & 0.03 & & & 0.03 & & & 0.05 & & & 0.03 \\
\hline Plumbago zeylanica & & & & & & & & 0.02 & 0.05 & & & \\
\hline Indigo suffruticosa* & & & & & & & & 0.06 & & & & \\
\hline Osteomeles anthyllidifolia & & & 0.03 & & & & & & & & & \\
\hline \multicolumn{13}{|l|}{ Herbs and vines } \\
\hline Asclepias physocarpa* & & 1.6 & 0.1 & & 3.00 & 0.10 & & 8.03 & 0.38 & & 14.37 & 0.23 \\
\hline Lactuca serriola* & 0.17 & 5 & 0.07 & & & 0.03 & 0.03 & 15.60 & 0.32 & & 0.07 & 0.03 \\
\hline Euphorbia peplus* & 0.03 & 7.03 & 0.26 & 1.83 & 5.60 & 0.03 & 0.02 & 0.23 & & & & \\
\hline Peperomia leptostachya & 2.17 & 0.17 & 0.9 & 1.80 & & 0.97 & 1.32 & 0.35 & 1.18 & 2.00 & 0.43 & 0.77 \\
\hline Sicyos lasiocephalus & & 5.43 & 0.13 & & & & & 0.02 & & & & \\
\hline Trifolium repens* & & 2.83 & & 0.10 & & & 0.03 & 0.57 & & & & \\
\hline Pennisetum setaceum ${ }^{*}$ & & & 0.03 & & & 0.67 & & 0.43 & 0.20 & & 0.77 & 0.20 \\
\hline Conyza bonariensis* & & & & & 1.17 & 0.03 & & 0.22 & & & 0.03 & \\
\hline Momordica charantia* & & & & & 0.20 & & 0.02 & 1.17 & & & 0.03 & \\
\hline Bidens pilosa* & & & & & & & & 0.18 & 0.05 & & 0.37 & 0.13 \\
\hline Senecio madagascarensis* & & & & & 0.07 & 0.03 & & 0.05 & 0.38 & & & \\
\hline Salvia coccinea* & & & & & & & 0.03 & & & 0.23 & & \\
\hline Solanum pseudocapsicum ${ }^{*}$ & & & & & & & & 0.13 & & & & 0.10 \\
\hline Argemone glauca & & & & & & & & 0.18 & & & & \\
\hline Solanum americanum ${ }^{*}$ & & & & & & & & 0.18 & & & & \\
\hline Cocculus orbicularis & & & & & & & & 0.07 & & & 0.10 & \\
\hline Canavalia hawaïensis & & 0.03 & & & & & & 0.10 & & & 0.03 & \\
\hline Mariscus hillebrandii & & & & & & 0.03 & & & 0.07 & & & 0.03 \\
\hline Ageratum conyzoides* & & 0.02 & & & 0.03 & & & 0.03 & & & & \\
\hline Agave sisalana* & & & & & & & & & & 0.07 & & \\
\hline Petroselinum crispum ${ }^{*}$ & & & & & & & & & 0.05 & & & \\
\hline Verbena litoralis ${ }^{*}$ & & 0.03 & & & & & & 0.02 & & & & \\
\hline \multicolumn{13}{|l|}{ Ferns } \\
\hline Phymatosorus grossus* & & & & 0.43 & & & 0.38 & & 0.02 & 0.43 & & \\
\hline Total number of species & 5 & 11 & 15 & 7 & 11 & 17 & 10 & 22 & 20 & 7 & 11 & 14 \\
\hline
\end{tabular}

* Indicates nonnative species.

tion site, and lowest in the unmanaged site (Table 1). In 2006, total species richness was highest in the short-term restoration site, intermediate in the long-term restoration site, and lowest in the unmanaged site. Patterns of abundance were dynamic at the species level, with some species appearing in only one site type and in only one or two census years (Table 1). Most juvenile herbaceous plants were of nonnative species, but those of trees and shrubs were primarily natives (Table 1).

Overall abundance was significantly affected by site, but relative differences were variable over time (Table 2). In particular, during four of the seven censuses (December 
TABLE 2

Output from ANOVA for the Following Dependent Variables: Seedling Abundance, Native Seedling Proportion, Native Seed Rain, and Seed of Nonnative Fountain Grass

\begin{tabular}{|c|c|c|c|c|}
\hline Parameter & $\begin{array}{c}\text { Seedling } \\
\text { Abundance }\end{array}$ & $\begin{array}{c}\text { Native } \\
\text { Proportion }\end{array}$ & $\begin{array}{l}\text { Native } \\
\text { Seed Rain }\end{array}$ & $\begin{array}{c}\text { Grass } \\
\text { Seed Rain }\end{array}$ \\
\hline \multicolumn{5}{|l|}{ Fixed effects } \\
\hline Site & $23 \cdot 6_{(2,127)}{ }^{* * *}$ & $5.29_{(2,8.53)}$ * & $10.32_{(2,6.57)}{ }^{* *}$ & $10.07_{(2,7.32)}$ ** \\
\hline Time & $10.97_{(6,424)}{ }^{* *}$ & $1.67_{(6,28.7)}$ & $4.06_{(6,19.9)}{ }^{* *}$ & $4.13_{(6,31.2)} * *$ \\
\hline Site* Time & $6.28_{(12,424)}^{(0,424 *}$ & $2.01_{(6,28.7)}^{(0,28) / 1}$ & $2.49_{(12,19.9)}^{(0,9)}$ * & $2.01_{(12,31.2)}^{(0,31 .)}$ \\
\hline \multicolumn{5}{|l|}{ Linear contrasts } \\
\hline $\begin{array}{l}\text { Unmanaged versus } \\
\text { (short-term + long-term) }\end{array}$ & $26.49_{(1,127)} * * *$ & $0.63_{(1,8.53)}$ & $13.19_{(1,6.57)}{ }^{* *}$ & $16.84_{(1,7.32)}$ ** \\
\hline Short-term versus long-term & $20.7_{(1,127)}$ *** & $9.95_{(1,8.53)}$ * & $7.46_{(1,6.57)}$ * & $3.3_{(1.732)}$ \\
\hline
\end{tabular}

Note: Table contains $F$ values for fixed effects of restoration history (site) and census date (time) and a priori linear contrasts. ${ }^{*} P<.05,{ }^{* *} P<.01,{ }^{* * *} P<.001$.

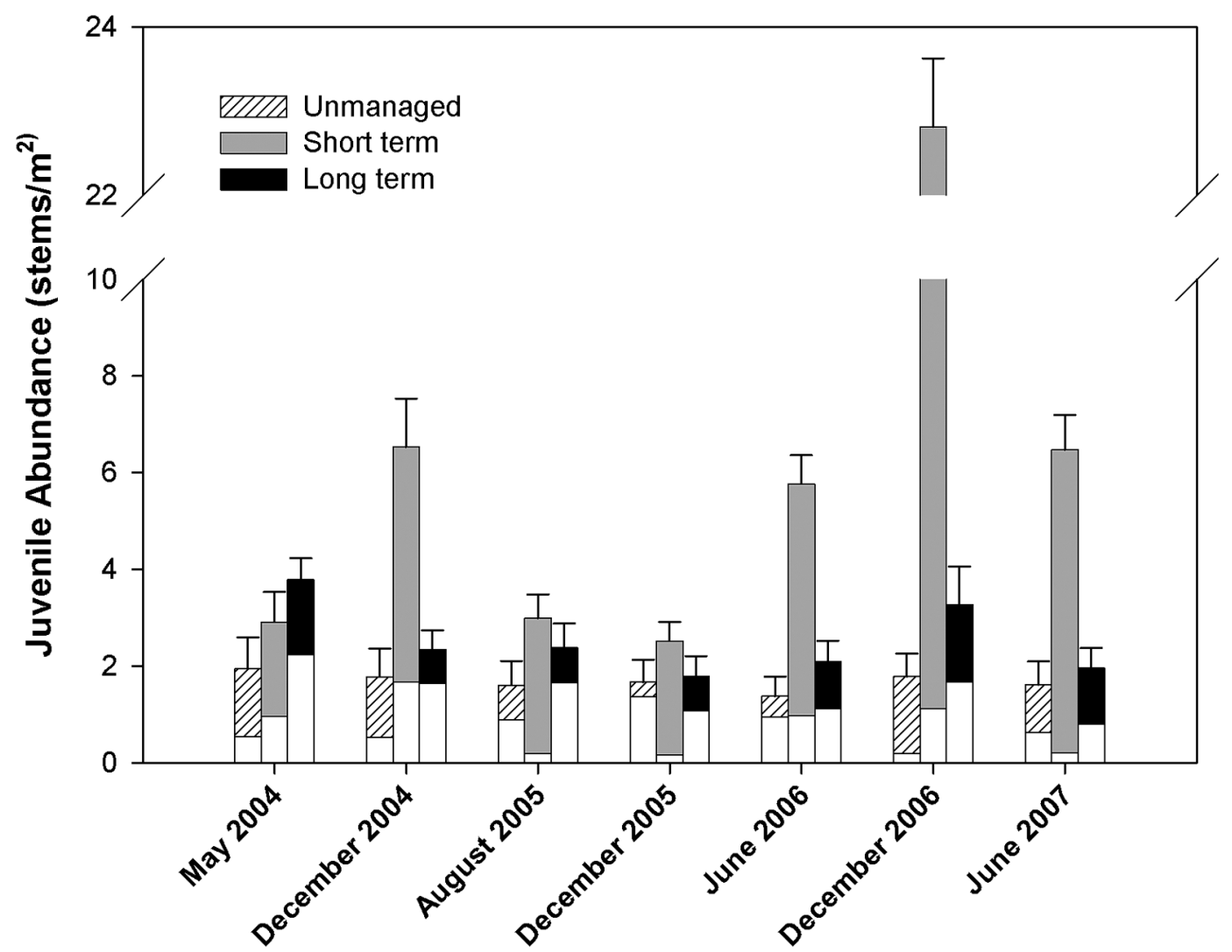

FIGURE 2. Juvenile abundance (stems $/ \mathrm{m}^{2} \pm \mathrm{SE}$ ) within unmanaged, short-term, and long-term restoration units at the Ka'ūpūlehu Preserve over seven census dates from May 2004 to June 2007. White fill in each bar indicates native proportion of total juvenile count. 
2004, June 2006, December 2006, and June 2007), the short-term restoration site contained more than three times as many juveniles as did the other sites (Figure 2). When pooled over time, both short-term and longterm restoration sites had higher overall abundance than the unmanaged site (Table $2)$. The native proportion of the total abundance differed among sites but not over time (Table 2). On average, native juveniles made up $85 \%$ of the individuals in the long-term restoration sites but only $32 \%$ in the shortterm restoration site (Figure 2).

The distribution of juveniles among height classes tended to vary among native and nonnative species and across sites and census dates (Figure $3 a, b, c$ ). At every census and in each site, natives in the smallest size class $(<10 \mathrm{~cm}$ height $)$ made up at least $57 \%$ of the natives present. In contrast, the size distribution of non-natives was more variable with the smallest ( $<10 \mathrm{~cm}$ height) individuals making up $\geq 90 \%$ of the non-native seedlings in at least one census in every site. In contrast, the smallest non-natives also made up $\leq 10 \%$ of non-natives in at least one census in every site (Figure $3 a, b, c)$. Nonnatives experienced peaks in abundance of the smallest stems both at the beginning of the study (2004) and again near the end (2006), particularly in short-term and long-term sites (Figure $3 b, c$ ). In contrast, during censuses in 2005 the size class distribution of nonnatives tended to shift toward larger sizes, with 23\% in short-term and $40 \%$ in the long-term site reaching $>1 \mathrm{~m}$ height. Nonnatives reached $>1 \mathrm{~m}$ height in all sites during the study, but natives did so only in short-term and longterm sites.

Small seedlings ( $<10 \mathrm{~cm}$ height) of native woody species occurred in all three sites, but recruitment into larger $(>10 \mathrm{~cm}$ height $)$ size classes was restricted to sites where grass was removed (Figure 4). We found seedlings from seven different native woody species: two canopy trees (Diospyros sandwicensis, Psydrax odorata) and five small trees/shrubs (Chenopodium oabuense, Nototrichium sandwicense, Osteomeles anthyllidifolia, Sida fallax, Sophora chrysophylla). Seedlings of these species were 2.5 times more abundant in the long-term
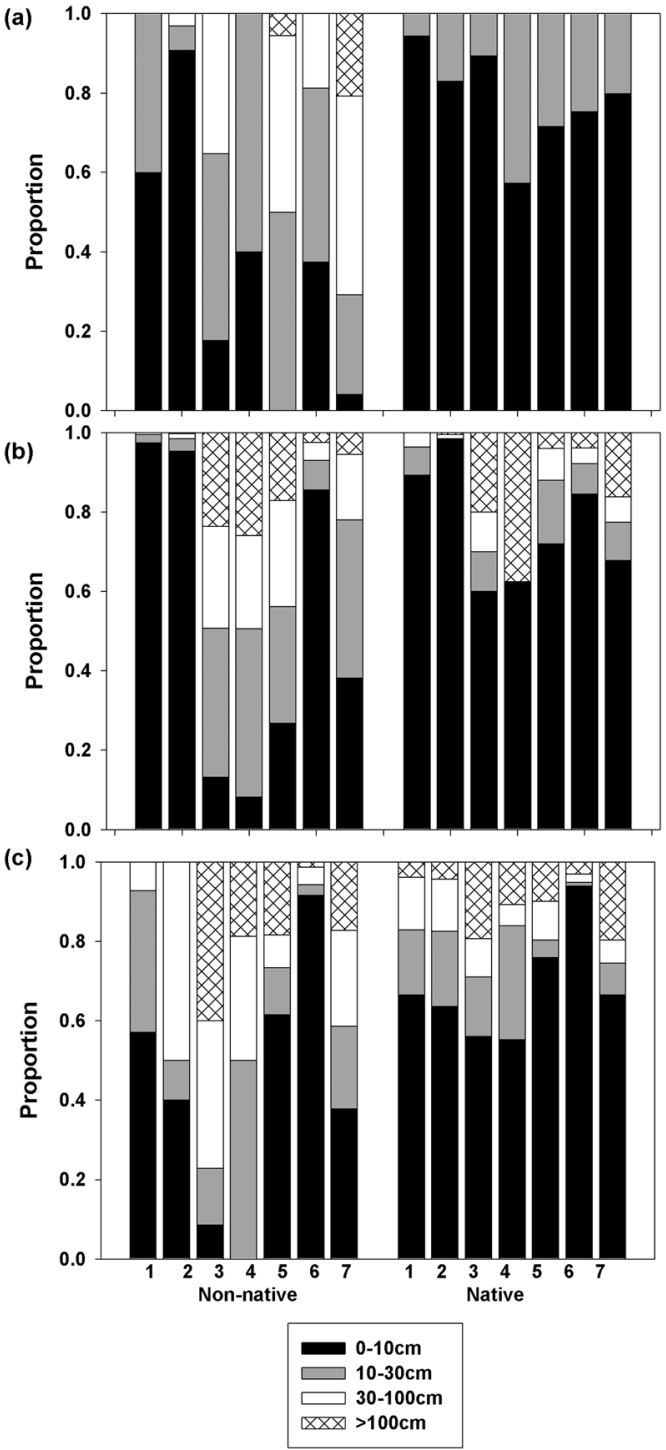

Figure 3. Proportion of nonnative and native juveniles in each of four height classes $(0-10 \mathrm{~cm},>10-30 \mathrm{~cm}$, $>30-100 \mathrm{~cm},>100 \mathrm{~cm})$ at each of seven census dates $(1$, May 2004; 2, December 2004; 3, August 2005; 4, December 2005; 5, June 2006; 6, December 2006; 7, June 2007) within (a) unmanaged, (b) short-term, and (c) long-term restoration units.

site than in either unmanaged or short-term sites $(F=8.08 ; \mathrm{df}=2,87 ; P<.001$ [Figure $4 a]$ ). Of these seedlings, $\sim 25 \%$ in both the long-term and short-term sites recruited into 


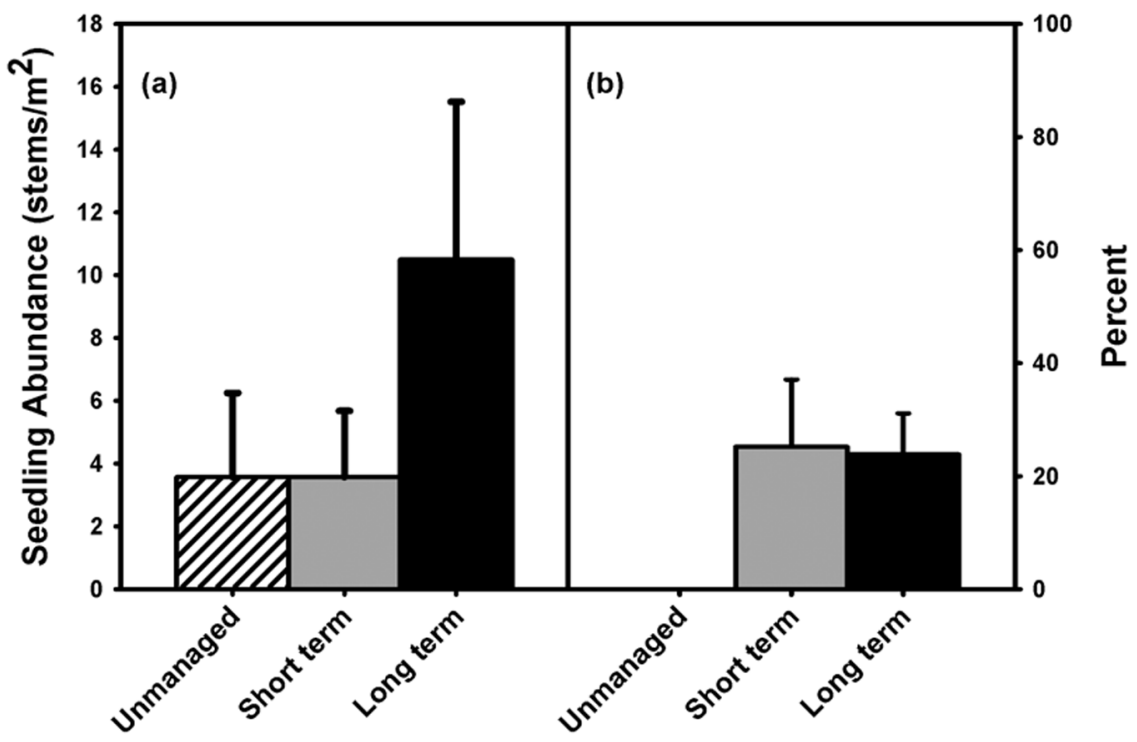

Figure 4. Pooled seedlings of two native canopy tree species (Diospyros sandwicensis, Psydrax odorata) and five native shrub species (Sophora chrysophylla, Chenopodium oabuense, Osteomeles anthyllidifolia, Nototrichium sandwicense, Sida fallax) within restoration units: (a) average seedling abundance over the study period (2004-2007), (b) percentage of these seedlings that recruited into a larger height class during the study.

a larger size class during the study, with some individuals reaching $100 \mathrm{~cm}$ height. In contrast, the maximum height of native woody seedlings in the unmanaged site was $<10 \mathrm{~cm}$ with no recruitment into larger size classes (Figure 4b).

We collected 2,508 seeds of nine native species over the 32-month collection period (Table 3). Native seed rain into the long- term site tended to be higher than that of either the short-term or unmanaged sites (Figure $5 a$ ). During four of the seven collection periods (November 2004-March 2005, January-April 2006, May-August 2006, and September-December 2006), seed rain into the long-term site was at least twice that of other sites. During the other three collection periods, native seed rain was uniformly low

\section{TABLE 3}

Average Monthly Seed Rain for Native Species from 2004 to 2007 within Long-Term (LT), Short-Term (ST), and Unmanaged (U) Units at the Ka'ūpūlehu Preserve on the Island of Hawai'i

\begin{tabular}{|c|c|c|c|c|c|c|c|c|c|c|c|c|}
\hline \multirow[b]{2}{*}{ Scientific Name } & \multicolumn{3}{|c|}{2004} & \multicolumn{3}{|c|}{2005} & \multicolumn{3}{|c|}{2006} & \multicolumn{3}{|c|}{2007} \\
\hline & $\mathrm{U}$ & ST & LT & $\mathrm{U}$ & ST & LT & $\mathrm{U}$ & ST & LT & $\mathrm{U}$ & ST & LT \\
\hline Canavalia hawaiiensis & & & & & & & & 0.01 & & & & \\
\hline Chenopodium oabuense & & & 27.7 & & & 0.25 & & & 2.3 & & & \\
\hline Diospyros sandwicensis & 0.03 & & 1.17 & 0.01 & 0.01 & 0.09 & 0.03 & & 0.05 & 0.01 & 0.01 & 0.13 \\
\hline Nototrichium sandwicense & & & & & & 0.06 & & 0.01 & 1.74 & & & 0.07 \\
\hline Peperomia leptostachya & & & & & & & & 0.03 & & & 0.03 & \\
\hline Psydrax odorata & & & & 0.26 & 0.02 & & 0.11 & 0.01 & & 0.46 & 0.02 & \\
\hline Sicyos lasiocephalus & & & 1.53 & & 0.53 & 1.32 & & 0.48 & 0.18 & & 0.23 & \\
\hline Sida fallax & & & 0.13 & & 1.21 & 0.01 & & & & & & \\
\hline Sophora chrysophylla & & & & & & & & & 0.05 & & & \\
\hline
\end{tabular}



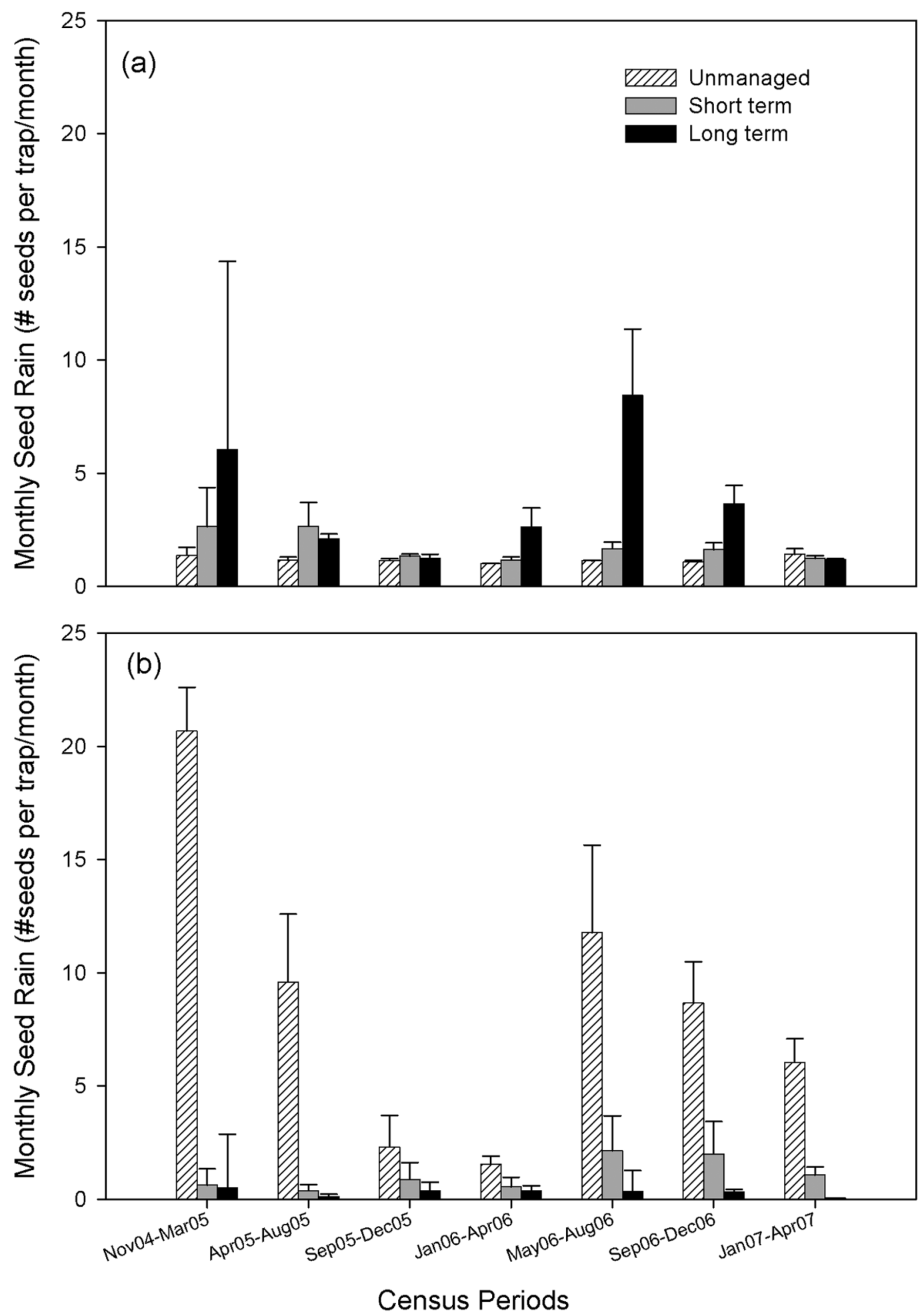

FIGURE 5. Average monthly seed rain (number/0.025 $\mathrm{m}^{2} \pm \mathrm{SE}$ ) within unmanaged, short-term, and long-term sites for seven collection periods from November 2004 to April 2007 for (a) native species and (b) nonnative fountain grass (Pennisetum setaceum). 
and did not differ between sites. This pattern resulted in significant effects of site, time, and a site by time interaction (Table 2). A significant linear contrast indicated that when pooled over time, native seed rain in the long-term site was significantly greater than that of the short-term site (Table 2).

We collected 5,390 fountain grass seeds during the same 32 months of collection. In contrast to native species seed rain, fountain grass seed rain in the unmanaged site was significantly higher than that in either the longterm site (26\% higher) or short-term site $(7 \%)$ over the same period (Figure $5 b$, Table $2)$. Fountain grass seed rain differed significantly over time (Table 2) and was highest during the first (November-March 2005) and fifth (May-August 2006) census periods, as was seed rain for native species (Figure $3 a, b)$.

\section{DISCUSSION}

Our results point to the importance of a long-term approach to restoration in Hawaiian dry forests. Native seed rain and native juvenile plant abundances were significantly higher in the long-term restoration site than in either the short-term restoration site or the unmanaged site. Long-term restoration activities may have contributed to this pattern in multiple ways. First, although Diospyros sandwicensis dominated the canopy at all sites, a diverse native shrub understory was present in the long-term site. Although most canopy trees are likely older than the initiation of restoration activities at the site, a relatively long history of ungulate exclusion and grass control appears to have contributed to the development of the shrub understory layer (Cabin et al. 2000). For this reason, seed rain produced by native shrubs such as Chenopodium oabuense, Nototrichium sandwicense, and Sida fallax (Table 3) in the long-term site can at least in part be attributed to past restoration activities.

A second way that long-term grass removal appears to be important is for overcoming initial recruitment pulses of fast-growing nonnative species. In both our short-term site and following initial grass removal
(1995) in the long-term site (Cabin et al. $2002 a$ ), nonnative species were very abundant. Pulses of nonnative recruitment have continued in both short-term and long-term sites, but both the relative and absolute abundance of natives are higher in the long-term site. Finally, because high-rainfall years are infrequent and unpredictable, a longer period of grass removal may increase the likelihood of viable native seeds occupying a grass-free site at a time when moisture conditions are likely to promote germination and establishment.

Our study also corroborated earlier work (Cabin et al. 2000) that suggested that fountain grass severely limits the recruitment and subsequent growth of native seedlings via competition for light and water. Although small seedlings of native species were found under fountain grass in the unmanaged site, very few of these grew into larger size classes. In particular for seedlings of native trees and shrubs, growth and recruitment into larger size classes was completely restricted to the two restoration sites where fountain grass had been removed. Similarly, a comparison of the population structure of two common native trees growing within a fountain grassinvaded and a relatively fountain grass-free Hawaiian dry forest found that although seedlings were present in both sites, the sapling size class was completely absent from the grass-invaded forest (Litton et al. 2006). Fountain grass creates extremely dense shade (Litton et al. 2008; J.M.T. and S.C., unpubl. data) and limits water availability near the soil surface (Cordell and Sandquist 2008; J.M.T. and S.C., unpubl. data), potentially accounting for these patterns. Other studies in both dry (Scariot et al. 2008) and wet areas (Zimmerman et al. 2000) have indicated that grass cover may enhance initial germination and establishment of tree seedlings but subsequently limit survival and growth (Zimmerman et al. 2000, Hooper et al. 2002). Hooper et al. (2002) suggested that invasive grasses limit tree regeneration primarily through increased belowground competition for water during the dry season.

The development of an understory shrub layer that provides partial shade (as is present 
within the long-term site) may be important to promoting natural regeneration in remnant Hawaiian dry forests. This understory layer has the capacity to enhance the survivorship of native seedlings particularly during drought conditions. In a previous study at the same site, Cabin et al. (2002a) found positive associations between naturally recruiting fastgrowing native shrubs and outplanted seedlings of native trees. A number of studies with tropical dry-forest species have found positive effects of shading (from tree canopy or shade structures) on germination and seedling survival particularly during dry periods (Lieberman and Li 1992, Ray and Brown 1995, Gerhardt 1996, Cabin et al. 2002b, McLaren and McDonald 2003, Viera et al. 2008). Thus restoration practices that promote the establishment and growth of fastgrowing, short-lived native species may create microsite conditions that in turn facilitate the regeneration of slower-growing latesuccessional species.

Results of our study have several implications for the practice of restoration within Hawaiian dry forests. First, it appears that when continued for a number of years, ungulate exclusion and grass removal can stimulate natural regeneration of native species in remnant Hawaiian dry forest. In this way, ungulate exclusion and grass removal contribute to the development of an understory of fastgrowing native shrubs, which increases the abundance and diversity of native seed rain. This in turn may increase the availability of native seeds in sites free from ungulates and nonnative grasses, thereby allowing native species to take advantage of infrequent highrainfall years through seedling regeneration.

\section{ACKNOWLEDGMENTS}

We are grateful to all members of the North Kona Dry Forest Working Group for their continued support of our research at $\mathrm{Ka}^{6} \mathrm{u} p \bar{p}$ lehu. In particular, we thank Y. YarberCarter for logistical support and Kamehameha Schools and the National Tropical Botanical Garden for site access. B. Paritosh, S. Brooks, F. Inman, N. Narahari, J. Carbone, M. Higashi, H. Hansen, O. Cole, and
S. Cole helped with fieldwork, and A. Yoshinaga helped with seed identification.

\section{Literature Cited}

Blain, D., and M. Kellman. 1991. The effect of water-supply on tree seed germination and seedling survival in a tropical seasonal forest in Veracruz, Mexico. J. Trop. Ecol. 7:69-83.

Bruegmann, M. M. 1996. Hawaii's dry forests. Endangered Species Bull. 11:2627.

Bullock, S. H., H. A. Mooney, and E. Medina. 1995. Seasonally dry tropical forests. Cambridge University Press, New York.

Cabin, R. J., S. G. Weller, D. H. Lorence, S. Cordell, and L. J. Hadway. 2002a. Effects of microsite, water, weeding, and direct seeding on the regeneration of native and alien species within a Hawaiian dry forest preserve. Biol. Conserv. 104:181-190.

Cabin, R. J., S. G. Weller, D. H. Lorence, S. Cordell, L. J. Hadway, R. Montgomery, D. Goo, and A. Urakami. 2002b. Effects of light, alien grass, and native species additions on Hawaiian dry forest restoration. Ecol. Appl. 12:1595-1610.

Cabin, R. J., S. G. Weller, D. H. Lorence, T. W. Flynn, A. K. Sakai, D. Sandquist, and L. J. Hadway. 2000. Effects of longterm ungulate exclusion and recent alien species control on the preservation and restoration of a Hawaiian tropical dry forest. Conserv. Biol. 14:439-453.

Cordell, S., and D. R. Sandquist. 2008. The impact of an invasive African bunchgrass (Pennisetum setaceum) on water availability and productivity of canopy trees within a tropical dry forest in Hawaii. Funct. Ecol. 22:1008-1017.

Cottrell, T. R. 2004. Seed rain traps for forest lands: Consideration for trap construction and study design. BC J. Ecosyst. Manage. $5: 1-6$.

Cuddihy, L. W., and C. P. Stone. 1990. Alteration of native Hawaiian vegetation: Effects of humans, their activities and introductions. Cooperative National Park Resources Studies Unit, University of Hawai'i at Mānoa, Honolulu. 
Gerhardt, K. 1996. Effects of root competition and canopy openness on survival and growth of tree seedlings in a tropical seasonal dry forest. For. Ecol. Manage. 82:33-48.

Hooper, E., R. Condit, and P. Legendre. 2002. Responses of 20 native tree species to reforestation strategies for abandoned farmland in Panama. Ecol. Appl. 12:16261641.

Janzen, D. H. 1988. Tropical dry forests, the most endangered major tropical ecosystem. Pages 130-144 in E. O. Wilson, ed. Biodiversity. National Academy Press, Washington, D.C.

Lieberman, D., and M. G. Li. 1992. Seedling recruitment patterns in a tropical dry forest in Ghana. J. Veg. Sci. 3:375-382.

Littell, R. C., G. A. Milliken, W. W. Stroup, and R. D. Wolfinger. 1996. SAS system for mixed models. SAS Institute, Inc., Cary, North Carolina.

Litton, C. M., D. R. Sandquist, and S. Cordell. 2006. Effects of non-native grass invasion on aboveground carbon pools and tree population structure in a tropical dry forest in Hawaii. For. Ecol. Manage. 231:105-113.

-2008. A non-native invasive grass increases soil carbon flux in a Hawaiian tropical dry forest. Glob. Change Biol. 14:726739.

McLaren, K. P., and M. A. McDonald. 2003. The effects of moisture and shade on seed germination and seedling survival in a tropical dry forest in Jamaica. For. Ecol. Manage. 183:61-75.

Miles, L., A. C. Newton, R. S. DeFries, C. Ravilious, I. May, S. Blyth, V. Kapos, and J. E. Gordon. 2006. A global overview of the conservation status of tropical dry forests. J. Biogeogr. 33:491-505.

Moore, R. B., D. A. Clague, M. Rubin, and W. A. Bohrson. 1987. Hualalai volcano: A preliminary summary of geologic, petrologic, and geophysical data. Pages 571-
585 in R. W. Decker, T. L. Wright, and P. H. Stauffer, eds. Volcanism in Hawaii. U.S. Geological Service Professional Paper 1350. U.S. Government Printing Office, Washington, D.C.

Ray, G. J., and B. J. Brown. 1995. Restoring Caribbean dry forests: Evaluation of tree propagation techniques. Restor. Ecol. 3:86-94.

Rock, J. F. 1913. The indigenous trees of the Hawaiian Islands. Reprinted in 1974 by Pacific Tropical Botanical Garden, Lāwa'i, Kaua'i, Hawai'i, and Charles F. Tuttle, Rutland, Vermont.

Sakai, A. K., W. L. Wagner, and L. A. Mehrhoff. 2002. Patterns of endangerment in the Hawaiian flora. Syst. Biol. 51:276-302.

SAS Institute. 2002-2003. SAS system for Windows, ver. 9.1. Cary, North Carolina.

Scariot, A., D. L. M. Viera, A. B. Sampaio, E. Guarino, and A. Sevilha. 2008. Recruitment of dry forest tree species in central Brazil pastures. Pages 231-244 in R. W. Myster, ed. Post-agricultural succession in the neotropics. Springer, New York.

Smith, C. W., and J. T. Tunison. 1992. Fire and alien plants in Hawai'i: Research and management implications for native ecosystems. Pages 394-408 in C. P. Stone, C. W. Smith, and J. T. Tunison, eds. Alien plant invasions in native ecosystems of Hawai'i: Management and research. Cooperative National Park Resources Studies Unit, University of Hawai'i at Mānoa, Honolulu.

Viera, D. L. M., V. V. de Lima, A. C. Sevilha, and A. Scariot. 2008. Consequences of dry-season seed dispersal on seedling establishment of dry forest trees: Should we store seeds until it rains? For. Ecol. Manage. 256:471-481.

Zimmerman, J. K., J. B. Pascarella, and T. M. Aide. 2000. Barriers to forest regeneration in an abandoned pasture in Puerto Rico. Restor. Ecol. 8:350-360. 